\title{
The Influence of the European Friends of Israel on the Members of the European Parliament
}

Ugur Burc Yildiz*

This article investigates how and why the European Friends of Israel, the most
powerful pro-Israel lobby in Brussels, has worked to influence members of the
European Parliament. It puts that the European Friends of Israel's lobbying
activities have composed of arranging meetings with senior Israeli politicians and
bureaucrats, organizing both policy and public conferences, taking policy initiatives
and organizing trips for missions. Within the framework of these activities, the
European Friends of Israel has aimed to influence the parliamentarians to take
decisions in line with Israel's security interests, such as over Iran's nuclear program
or Hamas, and ensure their support for some Israeli policies criticized by the
European Union, like the settlements. Given its financial power and well-organized
structure, it can be expected that the European Friends of Israel, which is still a
relatively new organization, will become more effective in lobbying in defense of
Israeli interests.

Key Words: $\quad$ European Friends of Israel, European Union, Members of the European Parliament, Israel, Lobbying.

\footnotetext{
* Assistant Professor at Department of International Relations in İzmir University. burc.yildiz@izmir.edu.tr
} 
Ugur Burc Yildiz

\section{Introduction}

The birthplace of lobbying is the United States (US), dating back to the early years of the establishment of the republic. Lobbying is now carried out by nearly 100,000 lobbyists in Washington D.C., with one of the most powerful lobbies being the pro-Israel American Israel

I 2 Public Affairs Committee (AIPAC), which was once defined by former US President Bill Clinton as better than anyone else at lobbying in Washington. ${ }^{1}$ Lobbying, however, has only developed in the European Union (EU) over the last 20 years as EU institutions have been granted more powers. Nevertheless, it is claimed today that 75 per cent of all EU legislation is, to a greater or lesser extent, influenced by lobbying. ${ }^{2}$

To take advantage of the increasing influence of lobbying in the EU, pro-Israel lobbies have been established in Brussels in the last 15 years, such as the European Friends of Israel (EFI), the Transatlantic Institute (TAI), B'nai B'rith and the European Jewish Congress (EJC). Among them, however, the most important pro-Israel lobby that has increased its power in recent years is the EFI, ${ }^{3}$ which follows AIPAC's method of targeting elected representatives. The factors contributing to the EFI's effectiveness include ignoring the EU's complex decision-making structure by specifically focusing on the Members of the European Parliament (MEPs), its powerful financial resources, well-organized structure and cleverly organized lobbying activities. Its members even claim that the EFI will one day become Europe's AIPAC. ${ }^{4}$ This article explores how and why the EFI has worked to influence MEPs. By analyzing its lobbying activities, which are not held behind the closed doors, the article concludes that the EFI exerts its influence via meetings, conferences, political initiatives and missions. Through these activities, it has intended to influence MEPs to take decisions in favor of Israel's security interests and support it regarding EU criticisms of particular Israeli policies.

The first section of this article briefly focuses on lobbying in the EU, including the development of lobbying, the lack of transparency in lobbying and a classification of lobbying organizations. The second section explains the launch, organizational structure and financial resources of the EFI. The third section broadly analyzes the activities that the EFI uses to influence MEPs and, with the help of this analysis, it explains the EFI's lobbying aims. The conclusion provides a general evaluation of the article.

\section{Lobbying in the European Union}

Lobbying has only gathered strength in the EU in the last 20 years. While interest groups and lobbies have been active in Brussels since the Rome Treaties, their size, range and type have changed significantly in the last two decades. In the early years of the European Community, national representation and collective action through trade unions, trade associations and employee groups characterized interest representation. However, starting in the early 1990s, business circles and non-governmental organizations decided to increase their power ${ }^{5}$ in Brussels because, starting from the Single European Act and continuing with the Treaty on the European Union, treaties granted more powers to institutions. To achieve their aims, both existing organizations and newcomers in Brussels equipped themselves with powerful financial resources and effective organizational structures. In response to increased lobbying, the EU was required to draw up lobbying regulations. Today, even though there are no precise figures for the number of lobbying organizations in the EU as registration is still not mandatory and there are different definitions of lobbying, ${ }^{6}$ there are at least 30,000 lobbyists in Brussels according to Corporate Europe Observatory, a non-profit research group aiming to expose the effects of corporate lobbying on EU policy-making. It is worth mentioning that lobbyists are estimated to influence 75 per cent of all EU legislation. ${ }^{7}$ To do this, it is essential for lobbyists to keep ahead of the start of political debates; otherwise, they cannot make an impact. ${ }^{8}$ 
Because lobbying ensures the participation of economic and social actors in decisionmaking processes, the EU's decision-makers consider lobbying activities positively. ${ }^{9}$ However, the lack of transparency over lobbying in EU institutions is an important problem for EU citizens, who have a right to expect these activities to comply with laws and ethical principles. In order to solve this problem, the Transparency Register was established in 2011, operated by the European Parliament and the European Commission. It brought a single code of conduct for all organizations and self-employed individuals to lobby according ethical principles. ${ }^{10}$ Registration with the Transparency Register covers all activities carried out which directly or indirectly influence EU institutions' formulation and implementation of policy and decision-making processes, irrespective of the channel or medium of communication used. ${ }^{11}$ It must be noted, however, that registration is not mandatory so transparency still remains very problematic. Transparency International, a global civil society organization fighting corruption, has several times advised the EU to introduce a mandatory joint register for the European Commission, the European Parliament and the Council of the EU (hereafter the Council) to prevent lobbyists exerting undue influence and increase EU citizens' trust in EU institutions. ${ }^{12}$

These three institutions are the main targets of lobbyists since they are the principal actors of the 'ordinary legislative procedure'. Because the legislative process starts with the European Commission, which has to consult with stakeholders when drafting legislation proposals, it is the most important target of lobbying activities. ${ }^{13}$ Lobbying activities in the European Parliament have significantly increased in the last 20 years after various treaties gave this institution more legislative powers. Today, under the ordinary legislative procedure, the European Parliament has the right to decide the contents of EU laws in many areas, including consumer protection, environment, agriculture, energy policy, immigration and EU funding. To a large extent, lobbying activities in the European Parliament occur in the Committees. Usually, through the ordinary legislative procedure, the Council negotiates and adopts legislations together with the European Parliament. However, it is difficult for lobbyists to influence the Council since representatives in this body are under the command of their national governments; thus, they do not seek technical information in Brussels. ${ }^{14}$ The ordinary legislative procedure complicates the job of lobbyists in Brussels since they have to reach all these actors.

The European Commission classifies groups aiming to influence EU decision-making as non-profit organizations (international, European and national associations and federations) and profit-making organizations (public-relations firms, legal advisers, and consultants). Non-profit organizations can be further divided into two categories by identifying their targets: organizations aiming to protect citizens' interests; and organizations aiming to protect producers' interests. The former group includes environmentalist organizations (such as the European Environmental Bureau), regional organizations (such as the Assembly of European Regions), social and community organizations (such as the European Anti-Poverty Network and the European Women's Lobby) and consumer rights organizations (such the European Consumers' Organization). Non-profit organizations aiming to protect producers' interests include business groups (such as large firms and business federations), which account for two-thirds of all lobbying organizations in the EU, trade associations (such as the European Federation of Pharmaceutical Industry Associations), groups representing the professions (such as the European Council of the Liberal Professions) and labor organizations (such as the Union of Industrial and Employers Confederation of Europe). ${ }^{15}$

Some business groups have actively lobbied to protect national commercial interests in Brussels, with US-friendly groups being the most effective, such as the Trans-Atlantic Business Council, the American Chamber of Commerce to the European Union and the EuropeanAmerican Industrial Council. Other major international actors also have business groups in Brussels, such as the EU-Russia Industrialist Round Table, the Japan Business Council in Europe and the EU-Chinese Business Association. Other countries, such as Belarus, Botswana, Ethiopia, Kazakhstan and Sri Lanka, however, have chosen to hire profit-making public affairs or public relations firms to gain political support, polish their image and prevent disadvantageous new regulations or secure preferential trade agreements and EU funding. ${ }^{16}$ Other countries with 
longstanding territorial military conflicts, particularly Armenia and Israel, have preferred to establish or support their own lobbyists in the EU to gain political support. For example, the European Friends of Armenia is a very important group that focuses on defending Armenian interests in the Nagorno-Karabakh conflict with Azerbaijan and having the 1915 events in the Ottoman Empire recognized as genocide by EU members. As mentioned earlier, important proIsrael lobbies in the EU include the EFI, TAI, the EJC and B'nai B'rith, primarily concerned with

I 4 protecting Israeli interests in the EU, especially regarding the Palestinian problem, Iran's nuclear program and commercial matters. The next section focuses on the EFI's establishment, structure and financial resources.

\section{The European Friends of Israel}

Pro-Israel lobbies are very powerful in the US because American Jews play a major role in the country's economic, cultural, intellectual and political life. The simplicity of decision-making process in Washington D.C. also eases their work. Apart from AIPAC, key pro-Israeli lobbies in the US include the American Jewish Congress, the Zionist Organization of America, the Israel Policy Forum, the American Jewish Committee, the Anti-Defamation League, the Religious Action Center of Reform Judaism, Americans for a Safe Israel, American Friends of Likud, Mercaz-USA and Hadassah (the Women's Zionist Organization of America). There are also several pro-Israeli think tanks connected with the lobby, such as the American Enterprise Institute, the Heritage Foundation, the Hudson Institute, the Center for Security Policy, the Foreign Policy Research Institute, the Institute for Foreign Policy Analysis and the Jewish Institute for National Security Affairs. ${ }^{17}$ The Israel lobby has two main strategies for increasing US support for Israel: influencing the policy-making processes in Washington; and ensuring that US public opinion supports Israel. Through the impact of the Israel lobby, the US has continued to provide Israel with military support to maintain its power in the Middle East, extensive diplomatic support in war and peace against Arab countries, and financial assistance for Israel's economic development or to rescue it during economic crises. ${ }^{18}$

Pro-Israel lobbies in the EU are less powerful in decision-making than their counterparts in Washington, partly because European Jews are less powerful in Europe's economic, cultural and political life. As a result, they have been less well-organized and resourced. In addition, the EU's complex decision-making structure makes lobbying more difficult. Nevertheless, this does not mean that pro-Israel lobbies are not influential in Brussels. After many years in which proIsraeli lobbying were performed by pro-Israeli US lobbyists, particularly AIPAC, Jewish people in the EU have recently managed to increase their involvement in lobbying after the creation of B'nai B'rith Europe in 1999, the TAI in 2004, the EFI in 2006, and the EJC's decision to open an office in Brussels in 2009. Of these, the EFI has been able to play a leading role in defending Israeli interests in EU decision-making by ignoring the EU's complex decision-making structure through specifically targeting the European Parliament via its MEPs. In addition, it has created a well-organized structure, gained powerful financial resources and organized clever lobbying activities.

Although the EFI's primary target is MEPs, it has also invited the EU's member states' national parliamentarians, particularly those who are members of Israel friendship groups in these states' parliaments, to its activities. In doing so, the EFI aims to bring together MEPs and friendship groups. Since it specifically focuses on MEPs, the EFI is different from the other proIsrael lobbies in the EU. ${ }^{19}$ As Cronin has noted, by being based around members of the different political party groups in the European Parliament, it seems very similar to AIPAC ${ }^{20}$ The EFI was created in 2006 by several pro-Israel MEPs and member state parliamentarians to institutionalize their efforts. Shortly before the gala launch of the EFI in Brussels on 13 September 2006, its CEO, Michel Gur Ari, explained its target as turning Europe into Israel's ally, with the founders expressing their hope that it would one day become the AIPAC of Europe. ${ }^{21}$ The EFI made its registration to the Transparency Register in 2011. 
The EFI was primarily established with the political aim of increasing EU support concerning the challenges Israel faces. In particular, as MEP Charles Tannock, one of its founding members, acknowledged, the EFI was necessary to counter the Palestinian solidarity movement within the EU: 'There is a clear need to reverse some of the demonizing of Israel and the black propaganda peddled by its enemies both within and outside of the EU. Israel is at the frontline in fighting international terrorism, which threatens us all, and therefore deserves our strong support'. ${ }^{22}$ The EFI also monitors all EU legislation regarding Israeli interests. ${ }^{23}$ The chairman of the Political Board of the EFI is Marek Siwiec, a Polish MEP in the Group of the Progressive Alliance of Socialists and Democrats in the European Parliament. Other members are MEPs from various political groups in the European Parliament. Apart from the Political Board, the EFI also has a Board of Administrators, consisting of major business figures, ${ }^{24}$ and two Steering Committees. The Steering Committee in the European Parliament includes MEPs with high-level experience of diplomacy, while the other Steering Committee includes the chairpersons of all the main parliamentary national-Israel friendship groups in EU member states. ${ }^{25}$

The EFI has declared in the Transparency Register that it had a total budget of $€ 400,000$ for 2012, with $€ 50,000$ estimated costs directly related to representing Israeli interests in EU institutions in that year. ${ }^{26}$ Its finances have mostly been in the form of donations from highranking business people, generally included on the Board of Administrators, and Zionist organizations in the US and Israel. Examples include Alexander Machkevitch, a mining tycoon with dual Kazakh and Israeli citizenship, Ronny Bruckner, a Belgian businessman, who founded Eastbridge, a company specializing in property and consumer goods, Marc Grossman, owner of Celio, a French men's clothing retailer, and Vladimir Sloutsker, a Russian businessman and the current President of the Israeli Jewish Congress. Regarding Zionist organizations, the New Yorkbased Near East Forum informed the America's Internal Revenue Service that it had given $\$ 33,000$ to the EFI for the 2009 tax year. ${ }^{27}$ The next section analyzes the EFI's activities to influence MEPs and the aims of these activities.

\section{The Lobby in Action}

Since its inception, the EFI has used meetings, conferences, political initiatives and missions as lobbying activities to influence MEPs. On 13 September 2006, the EFI held its first Brussels meeting with its gala launch, for which it managed to gather together 200 MEPs and national parliamentarians, and senior EU officials, including Benita Ferrero-Waldner, European Commissioner for External Relations, and Elmar Brok, Chairman of the European Parliament's Committee for Foreign Affairs. The gala launch was full of messages aiming to show that Israel is not alone in Europe. For instance, Gunnar Hökmark, Chairman of the Steering Committee of the EFI in the European Parliament and President of the Swedish-Israel Friendship Association, declared that 'Never have we seen parliamentarians from so many member states of the European Union, never have so many friends of Israel come together at the same time,' and continued, 'Please take this message ... We are friends of Israel, we are many and we come from all over Europe to stand up for Israel' ${ }^{28}$ On 9 October 2007, the EFI managed to gather a similar crowd of MEPs, national parliamentarians and policy advisors to a cocktail dinner for the inauguration of its new offices in Brussels. Although Hans-Gert Pöttering, President of the European Parliament, did not attend, he sent a noteworthy message in which he stated his confidence about the role that the EFI could play to spread democracy and peace in the Middle East. ${ }^{29}$

Sharing as it does the same sensitivities as the Israeli government, one of the issues that the EFI has given significant attention to is Iran's nuclear program. In June 2008, in order to inform MEPs about Iran's recent activities and persuade them to impose harsher economic sanctions, the EFI hosted Reuven Rivlin, currently President of Israel but at that time a member of the Knesset and former Speaker of the Knesset (2003-2006). Having urged the MEPs to impose further economic sanctions on Iran, Rivlin advised them to meet Iranian leaders in order to tell them that they could no longer continue with their present policies. 'If they don't hear this 
message, they don't see any pressure from the EU, they should report back how they are getting banned by the whole world', said Rivlin. He also informed MEPs that there was no prospect of negotiations with Hamas: 'We don't take communication with them as negotiations for peace but as negotiations of war, as far as they don't recognize the State of Israel and don't stop attacking our civilians'. ${ }^{30}$

On 5 March 2013, Israeli President Shimon Peres arrived in Brussels to conduct several meetings in areas including Syria's chemical weapons, Iran's nuclear program, the Middle East peace process and strengthening the strategic relationship between the EU and Israel. ${ }^{31}$ The EFI did not miss the opportunity to organize a meeting for Shimon Peres, which was held at the European Parliament in the morning of 6 March, and attended by more than 30 MEPs and parliamentary assistants, administrative staff and policy advisers of the European Parliament. The issues discussed in the meeting concerned the place of Israel in the Middle East, Iran and Syria. ${ }^{32}$ In the afternoon of the same day, the Political Board of the EFI visited Martin Schulz, President of the European Parliament, where they discussed future resolutions regarding the Middle East, how Knesset members and the government of Israel could be more influential in Europe, a letter to Catherine Ashton, the High Representative of the Union for Foreign Affairs and Security Policy and the Vice President of the European Commission, to take a harsh position against Turkey's Prime Minister Recep Tayyip Erdoğan, and the Agreement on Conformity Assessment and Acceptance of Industrial Products between the EU and Israel. ${ }^{33}$

Two of the Israeli policies that particularly trouble the EU, and over which it has criticized Israel many times, concern the human rights of Palestinian prisoners and the Israeli application of administrative detention. Based on British Mandate emergency legislation from 1945, Israeli law allows Israeli authorities to detain suspects without criminal indictment and trial, often without evidence. According to Israeli parliamentarian Ibrahim Sarsur, this enables Israel to detain Palestinians 'who undoubtedly have no connection to violent acts, such as parliamentarians, academics, students, merchants and the like.' In addition, he claims that 'these arrests are politically motivated, meant to pressure the Palestinian side and embarrass Mahmoud Abbas' ${ }^{34}$ Regarding EU criticisms, on 16 February 2013, Ashton called on Israel to fully respect international human rights obligations towards Palestinian detainees and prisoners. She also reiterated the EU's longstanding concern about the extensive use by Israel of administrative detention orders: 'Under international law, detainees have the right to be informed about the reasons underlying any detention and to have the legality of their detention determined without undue delay. The EU calls upon Israel to bring formal charges against any individuals detained, with a view to bring them to a fair trial without undue delay,. ${ }^{35}$ The European Parliament also criticized Israel for using administration detentions to restrict Palestinian political activism and applying this procedure for an unlimited period of time without pressing charges. ${ }^{36}$ Affected by the EU's sensitivity, the EFI, on 25 June 2013, organized a briefing to MEPs at the European Parliament given by Ady Niv, attorney at the Department of Special International Affairs in Ministry of Justice of Israel. In his briefing, Niv, among other judicial issues, tried to justify the policies by stressing that Israel only implemented administrative detention as a last resort based on solid evidence that detainees could be involved in future criminal acts like terrorism. ${ }^{37}$

Another way that the EFI has influenced EU parliamentarians is through organizing conference events. On 29 November 2006, for example, the EFI held a press conference at the European Parliament about three kidnapped Israeli soldiers, Gilad Shalit, Udi Goldwasser and Eldad Regev. After the press conference, the EFI organized a meeting between the families of these kidnapped soldiers and MEP Elmar Brok, Chairman of the European Parliament Committee on Foreign Affairs. In the meeting, Hökmark, after emphasizing the role played by the EU in Lebanon after the 2006 war and the financial aid it provides to Palestinian Authority, demanded that the EU help Israel ensure the safe return of the abducted soldiers. ${ }^{38}$

Israel has attached great significance to stopping Iran's nuclear program because of its fear that there would be a shift in Middle East power politics against Israel, and that Iran's Islamist leaders might one day decide to use nuclear weapons against Israel. Thus, on 7 March 2007, the EFI organized a conference event entitled 'Economic Sanctions against Iran' with the 
aim of persuading MEPs to vote for stronger sanctions. The conference drew the MEPs' attention to the fact that the productivity of the Iranian economy depends on imports of EU equipment and industrial products, particularly from Germany, and also reminded them that, whereas the US has not had trade relations with Iran since 1980, 35 per cent of Iran's imports come from the EU, which severely discomforts Israel. The MEPs heard how Europe could be affected by Iran's nuclear program. More specifically, it was claimed that the leaders of Iran have promised that Iran will transfer the knowledge for developing nuclear weapons to other regimes, which could result in terrorist attacks against Europe; that Iran has trained suicide bombers for such missions, including in Europe; that the Iranian regime's representatives have declared that they will wipe out liberal democracies, which would be easier with nuclear weapons; that Iran now has the capacity to strike Eastern Europe and Germany with its recently acquired and nuclear-capable BM-25 missiles with their 3,500 km range. The conference concluded that the 'nightmare' of an Iranian nuclear bomb could only be prevented if the EU, without delay, imposed comprehensive sanctions against Iran..$^{39}$ In February 2012, to update MEPs and staff of the European Parliament (more than 90 MEPs, policy advisers, assistance and activists attended) about the Iranian nuclear program and its implications for the EU, the EFI organized a further conference, in cooperation this time with The Israel Project, the US-based non-governmental organization that works to protect Israel by improving its image. The conference heard a lecture by Simon Henderson of the Washington Institute for Near East Policy, ${ }^{40}$ a pro-Israel think tank in Washington D.C.

The EFI has also organized policy conferences to strengthen understanding between Israel and Europe and to call for upgrading relations. The first took place in Paris on 5-7 November 2008, five months after the EU-Israeli Association Council decided to upgrade bilateral ties, with the participation of Gilad Shalit's father, Noam Shalit. The EFI managed to gather together hundreds of parliamentarians, including MEPs, and parliamentarians from the Council of Europe and the Knesset. Hans-Gert Pöttering, President of the European Parliament, and Luis Maria de Puig, President of the Parliamentary Assembly of the Council of Europe, also attended. As the EFI later commented, 'This impressive gathering made it the first-of-its-kind event in Europe since the establishment of the State of Israel' ${ }^{41}$ The primary target of this significant gathering was the United Nations Relief and Works Agency for Palestinian Refugees in the Near East (UNRWA), which Israel blames for prolonging the Palestinian problem by giving Palestinian refugees' children refugee status. For instance, Paul Casaca, an MEP from Portugal and EFI member, said of UNRWA that 'They are kept on a hate-machine ... Instead of helping the refugees we are helping those who want to use the refugees against the State of Israel'. ${ }^{42}$ The participants also adopted the Paris Declaration, which, among other points, emphasized the importance of developing closer and stronger relations between EU and Israel, while Noam Shalit used the meeting to call on Europeans to help to free his son from Hamas captivity. ${ }^{43}$

On 15 April 2009, the EFI intelligently hosted two controversial figures, Nonie Darwish and Tawfik Hamid, at a conference at the European Parliament entitled 'Hamas: Obstacle to Peace', to convince MEPs that it was dangerous and pointless for Europeans to engage with Hamas in the peace process. Darwish, the daughter of Egyptian Army lieutenant general Mustafa Hafez, who established the fedayeen to attack Israel's southern border between 1951 and 1956, and who was eventually killed by the Israeli Defense Forces, is known for her very harsh criticisms of Islam since the September 11 terrorist attacks. She also blames Arabs from her father's death, for example once stating that 'They killed my father because the fedayeen were killing Israelis'. ${ }^{44}$ When addressing MEPs at the EFI's conference, she specifically focused on her childhood memories of the Gaza Strip to discourage EU funding, claiming that 'Money was never given to housing and factories, it was always to fund organizations such as the fedayeen in the 1950s and Hamas today'. Regarding Europe's engagement with Hamas, she claimed that 'the conflict is not over land anymore. Listen to what they are saying in Arabic to their citizens. They are subjected to daily indoctrination to kill Jews whenever [they] find them ... By talking to Hamas we say that terrorism and violence are the way of doing things'. ${ }^{45}$ Hamid, a former member of the Al Gama'a al-Islamiyya (an Egyptian Sunni Islamist movement, considered by the $\mathrm{UN}$ and the EU as a terrorist organization) but today a senior fellow and chair for the study of Islamic radicalism at the Potomac Institute for Policy Studies, was introduced by the EFI to MEPs 
as a man with exceptional knowledge about the jihadi mindset. He first told MEPs that, because Hamas are liars, accepting and legitimizing it represents an obstacle to peace, before posing the following question: 'If the international community tells Hamas that via terrorism and killing civilian we still legitimize you, why would you turn to the path of peace?' ${ }^{46}$

The EFI's second policy conference took place in Jerusalem on 4-7 February 2011, with the participation of 120 MEPs (one sixth of the total number) and 400 other European national politicians. The EFI noted that this was the first time that such a large number of politicians had gathered in Israel ${ }^{47}$ while David Cronin remarked on the EFI's generosity in only requesting a non-mandatory $€ 300$ for the whole trip, even though a return flight from Brussels to Tel Aviv with El Al was $€ 570$, which illustrates that the EFI has powerful financial resources. ${ }^{48}$ The keynote speaker was Israeli President Shimon Peres, with Prime Minister Benjamin Netanyahu also addressing participants in the Knesset's Chagall Hall. In his speech, Netanyahu first drew the attention of the participants to their shared values, such as democracy, human rights and peaceful coexistence, before underlining that the greatest threat to these values was militant Islamist groups in the Middle East and Iran: 'They see the United States as the great Satan, we're the little Satan, and you're somewhere in between. You're a middle-sized Satan. That's how they view us, and there's no room in the world, in their world, for us and for our societies'. As a concluding remark, he emphasized that 'European Friends of Israel are the European Friends of Europe. They are the European friends of our common civilization, our common roots, our common values, our common aspirations for the future' ${ }^{49}$ The EFI also organized several visits for participants to the Israeli Aerospace Industry, the Holocaust History Museum (Yad Vashem), and the Ofra, Gush Etzion, Kfar Adumin settlements. ${ }^{50}$ It is essential to note that participants visiting these illegal settlements were breaching international law since Article 49 of the Fourth Geneva Convention stipulates that the occupying power shall not deport or transfer parts of its population into the territory it occupies.

Israel has also been sharply criticized for many years regarding women's rights, particularly by concerned international non-governmental organizations and activists. In 2011, the European Commission, in its European Neighbourhood Policy country report for Israel, also criticized Israel for insufficiently protecting women's rights. The Report highlighted the widening wage gap disfavoring women, the small proportion of women in ministerial positions and their underrepresentation in local government, the high unemployment rate of Arab women, and the continued trafficking of women into Israel for sexual exploitation. The Report also pointed out that, according to the 2010 World Economic Forum report, Israel slipped seven places in the gender quality world rankings compared with 2009. ${ }^{51}$ In response, on 25 April 2012, the EFI, together with The Israel Project, arranged a public conference in the European Parliament for MEPs. The speaker at the conference was Knesset member Einat Wilf, whose arguments supporting Israel regarding women's rights problems centered on the relatively high percentage female parliamentarians in the Knesset and Israel's relatively good treatment of women compared to Arab countries. ${ }^{52}$

On 22 January 2013, the EFI organized a further one-day conference in the European Parliament, entitled 'Myths and Reality: The European Union and the Middle East', attended by more than 300 MEPs, policy advisers and representatives of civil society organizations and think tanks. The first panel was on 'EU and Syria: Foreign Fighters and Refugees', the second on 'EU and Iran: Nuclear Policy and European Diplomacy', and the third on 'EU and Israel/Palestine: Peace, Conflict and the Future'.$^{53}$ The majority of speakers chosen by the EFI were hawkish supporters of Israel and neoconservatives, such as Oren Kessler, a research fellow on the Middle East at the Henry Jackson Society, a London-based think tank aimed at promoting American military strength, and Peter Neumann, director of the Kings College London's Centre for the Study of Radicalization. Neumann presented his institution's study about European fighters in Syria, arguing that many were 'genuinely altruistically motivated', and suggesting that there was a 'need for something more innovative than simply putting them in prison' after their return to Europe, which received an overwhelmingly positive response from the participating MEPs. ${ }^{54}$ 
Apart from organizing meetings and conferences, the EFI has also worked to influence the MEPs through political initiatives and missions. On 22 July 2013, for example, the EU decided to add the military wing of Hezbollah to its list of terrorist organizations because of Hezbollah's suspected involvement in bombings in Europe and its increasing role in Syria's civil war. This was strongly criticized by Hezbollah and Iran, who claimed that it was the result of Israeli and US pressure. ${ }^{55}$ The EU's decision was good news for the EFI because one of its most important aims was to ensure that the EU took such a decision, although the EFI had hoped for Hezbollah as a whole to be declared a terrorist organization. To achieve this, for example, the EFI released a written declaration on 13 June 2008, which it placed in the public register in the European Parliament, ${ }^{56}$ as well as calling on its supporters to sign a petition on 17 October 2012.

The EFI's biggest failure, and indeed that of all the pro-Israeli EU lobbyists, was their inability to prevent the EU's adoption, despite also pressure from John Kerry, US Secretary of State, of its 'Guidelines on the eligibility of Israeli entities and their activities in the territories occupied by Israel since June 1967 for grants, prizes and financial instruments funded by the EU from 2014 onwards' on 19 September 2013 in response to Israel's continued settlement activities in the occupied territories. ${ }^{57}$ The guidelines bring that Israel must indicate in any future agreements with the EU that all its settlements in the occupied territories are outside the state of Israel. Regarding grants and prizes, the EU guidelines state that the activities of any Israeli entities will be considered illegal if they take place in the occupied territories. Regarding financial instruments, such as loans, Israeli entities will be considered ineligible as final recipients if they operate in the occupied territories, whether inside the framework of EU-funded financial instruments or not. ${ }^{58}$ On 22 October 2013, after its multifaceted campaign in the European Parliament to head off the guidelines failed, the EFI formulated an open letter to MEPs, calling on Catherine Ashton, the High Representative of the Union for Foreign Affairs and Security Policy, to take action against the guidelines. ${ }^{59}$ The EFI's common letter was so effective that by three weeks later 27 MEPs from across the political spectrum had called on Ashton to take all necessary steps to withdraw the European Commission's guidelines. Using the arguments as presented in the EFI's letter, the MEPs asserted that scientific cooperation would be seriously damaged because the Israeli government's had retaliated against the guidelines by refusing to join Horizon 2020 , the EU's largest research and innovation programme with almost $€ 80$ billion of funding over seven years (2014-2020), to which Israel had pledged to contribute a further $€ 600$ million. The MEPs also claimed that the guidelines would also harm the recently re-launched USsponsored peace process between the Israelis and Palestinians. ${ }^{60}$

The EFI's missions include visits of its MEP teams to EU member states, the organization of trips to the Auschwitz concentration camp for MEPs, national parliamentarians of EU member states and Knesset members to commemorate European Holocaust Remembrance Day, and trips to Israel for MEPs, policy advisors from the European Parliament and national parliamentarians. Visits to EU member states have two purposes. The first is to introduce the EFI to newly-created Israeli parliamentary friendship groups and inform them that EFI can provide them with relevant information and sufficient support for their activities, ${ }^{61}$ such as the EFI's mission to Portugal on 25 January 2007. The second purpose is to meet with parliamentarians from across the political spectrum, ministers of foreign affairs and chairpersons of committees of foreign affairs in the parliaments, and ambassadors, such as the missions of the EFI to Spain on 20 February 2007, and to Malta on 5 May 2007. ${ }^{62}$ In December 2012, the EFI Political Board also made a solidarity visit to Israel, where they met with Israeli President Shimon Peres, to give their support to Operation Pillar of Defense, Israel's eight-day military assault against the Gaza Strip (14-21 November 2012), and to receive advice on how to react after the UN General Assembly granted the Palestinian Authority non-member observer state status in the UN on 29 November $2012 .{ }^{63}$ The trips to Auschwitz, where nearly 1.1 million prisoners were killed - around 90 per cent of them Jews, represent one of the EFI's principle missions. Since its establishment in 2006, the EFI has organized five trips for European Holocaust Remembrance Day with the participation of MEPs, parliamentarians from national parliaments and Knesset members. By presenting an opportunity for European parliamentarians to remember this tragedy, the EFI aims to influence them emotionally so as to ensure they stand against rising anti-Semitism. ${ }^{64}$ 
The EFI has also sponsored trips to Israel, both in war and peace time, for MEPs, parliamentarians in EU member states and policy advisors. During the Operation Cast Lead, for example, the heavy military assaults against the Gaza Strip between 27 December 2008 and 18 January 2009, in response to rocket strikes by Hamas militants against random targets inside Israeli borders, the EFI brought 9 MEPs and national parliamentarians to Sderot, on 6 January 2009, an Israeli city located less than a mile from the Gaza Strip, which had become a main

| 10 target. The EFI explicitly organized the trip to show the visitors the horrific situation facing thousands of Israeli citizens living close to the Gaza Strip. ${ }^{65}$ Another trip took place between 18 and 21 June 2013 for eight policy advisors from the European Parliament, who were taken to Israel's borders with Syria, Lebanon and the Gaza Strip to be addressed by senior military officers about the threats from these countries, before being invited to enjoy Tel Aviv's lively nightlife. ${ }^{66}$

\section{Conclusion}

There are two important factors that make lobbying in the EU difficult for the pro-Israel lobbies. First, Jews have a less influential role in European political, economic and social life than in the US, where they are powerfully integrated with, and play a major role in, every segment of life. Second, the complexity of the EU's ordinary legislative procedure forces pro-Israel lobbies to deal with the European Commission, the European Parliament and the Council to influence EU laws. As a way of overcoming these difficulties, the EFI's specific focus on MEPs should be considered as a very rational strategy because it has enabled the EFI to avoid wasting money and effort by focusing just on MEPs with cleverly organized lobbying activities. In addition, this strategy has also involved filling the EFI's organizational structures not only with Jews but also leading Christian politicians and businessmen. As a result, the EFI has become the most powerful pro-Israel lobby in Brussels today, although it is still relatively a new organization, established only in 2006.

Since its establishment, the EFI has tried to influence MEPs through meetings, conferences, political initiatives and missions. Through these lobbying activities, the EFI has aimed to influence MEPs in line with Israeli security interests and take their support for EU criticism of particular Israeli policies. The EFI's aim of ensuring that MEPs act in line with Israeli security interests included the following: preventing EU funding of the Hamas-controlled Gaza Strip; ensuring the EU imposes more sanctions against Iran because of its nuclear program; convincing MEPs to participate in negotiations with Iranian leaders regarding the country's nuclear program; cutting off EU trade relations with Iran, particularly Germany's; having the EU officially recognize Hezbollah as one entity as a terrorist organization; preventing the EU from engaging with Hamas in the peace process. EFI's works to get the support of MEPs in face of EU criticism of particular Israeli policies included the human rights conditions of Palestinian prisoners, controversial administrative detentions, women's rights, and Israeli settlements in the occupied territories. EFI is likely to continue its lobbying activity more effectively in the coming years since it has a specific target (the European Parliament via its MEPs), a well-organized structure and sufficient financial resources. It is, however, unrealistic to expect that the EFI will become Europe's AIPAC because the members of latter organization have been deeply embedded in American life for many years.

\section{Notes}

\footnotetext{
${ }^{1}$ Mearsheimer, J. J., and S. M. Walt. (2007). The Israel Lobby and U.S. Foreign Policy. New York: Farrar, Straus and Giroux, p. 153.

2 The Guardian. (2014). 30,000 Lobbyists and Counting: Is Brussels under Corporate Sway. May 8, http://www.theguardian.com/world/2014/may/08/lobbyists-european-parliament-brussels-corporate (accessed 10 May 2014).
} 
${ }^{3}$ Cronin, D. (2011). Europe's Alliance with Israel: Aiding the Occupation. New York: Pluto Press, p. 137.

4 Ynetnews. (2006). First Pro-Israel Lobby in EU Set Up. September 6, http://www.ynetnews.com/articles/0,7340,L-3300374,00.html (accessed 20 September 2014).

${ }^{5}$ Coen, D., and Jeremy Richardson. (2009). Learning to Lobby the European Union: 20 Years of Change. In Lobbying the European Union: Institutions, Actors, and Issues, 3-19. Oxford and New York: Oxford University Press, p. 5-6.

${ }^{6}$ Zibold, F. (2013). Lobbying the EU Institutions. Library Briefing, Library of the European Parliament, June

http://www.europarl.europa.eu/RegData/bibliotheque/briefing/2013/130558/LDM_BRI(2013)130558_REV 1_EN.pdf (accessed 10 September 2014).

${ }^{7}$ The Guardian. (2014). 30,000 Lobbyists and Counting: Is Brussels under Corporate Sway. May 8, http://www.theguardian.com/world/2014/may/08/lobbyists-european-parliament-brussels-corporate (accessed 10 May 2014).

${ }^{8}$ The New York Times. (2013). Lobbying Bonanza as Firms Try to Influence European Union. October 18, http://www.nytimes.com/2013/10/19/world/europe/lobbying-bonanza-as-firms-try-to-influence-europeanunion.html?pagewanted=all\&_r=0 (accessed 13 May 2014).

${ }_{9}$ Zibold, F. (2013). Lobbying the EU Institutions. Library Briefing, Library of the European Parliament, June 18, p. 1.

10 European Commission. (2014). Why a Transparency Register. http://ec.europa.eu/transparencyregister/info/about-register/whyTransparencyRegister.do?locale=en (accessed 27 september 2014).

11 European Commission. (2011). An Agreement between the European Parliament and the European Commission on the Establishment of a Transparency Register for Organizations and Self-Employed Individuals Engaged in EU Policy-Making and Policy Implementation. Official Journal of the European Union, L 191/29, July http://eurlex.europa.eu/LexUriServ/LexUriServ.do?uri=OJ:L:2011:191:0029:0038:EN:PDF (accessed September 17, 2014).

12 Transparency International. (2014). Transparent Lobbying Rules for All EU Institutions. http://archive.transparency.org/regional_pages/europe_central_asia/eu_liaison_office/eu_lobbying

(accessed 26 November 2014).

${ }^{13}$ European Parliament. (2003). Lobbying in the European Union: Current Rules and Practices. DirectorateGeneral for Research, p. 40. http://www.europarl.europa.eu/RegData/etudes/etudes/join/2003/329438/DG4-AFCO_ET(2003)329438_EN.pdf (accessed 17 September 2014).

${ }^{14}$ Coen, D., and Jeremy Richardson. (2009). Learning to Lobby the European Union: 20 Years of Change. In Lobbying the European Union: Institutions, Actors, and Issues, 3-19. Oxford and New York: Oxford University Press, p. 10.

${ }^{15}$ European Parliament. (2003). Lobbying in the European Union: Current Rules and Practices. DirectorateGeneral for Research, p. http://www.europarl.europa.eu/RegData/etudes/etudes/join/2003/329438/DG-4-

AFCO_ET(2003)329438_EN.pdf (accessed 17 September 2014).

${ }^{16}$ Corporate Europe Observatory. (2010). Lobbying for Governments in Brussels: A Lucrative Business still under the Radar. Report, $\quad$ p. http://corporateeurope.org/sites/default/files/sites/default/files/files/resource/ceo-lobbying-forgovernments.pdf (accessed 18 September 2014).

${ }^{17}$ Mearsheimer, J. J., and S. M. Walt. (2007). The Israel lobby and U.S. foreign policy. New York: Farrar, Straus and Giroux, p. 116-7.

${ }^{18}$ Ibid, p. 23, 151.

19 Jerusalem Post. (2014). The European Friends of Israel- Bilateral Challenges in a Global Context. January 19, http://www.jpost.com/Opinion/Op-Ed-Contributors/European-Friends-of-Israel-Bilateralchallenges-in-a-global-context-338658

${ }^{20}$ Cronin, D. (2011). Europe's Alliance with Israel: Aiding the Occupation. New York: Pluto Press, p. 138. 21 Ynetnews. (2006). First Pro-Israel Lobby in EU Set Up. September 6, http://www.ynetnews.com/articles/0,7340,L-3300374,00.html (accessed 20 September 2014).

22 Cited in Cronin, D. (2011). Europe's Alliance with Israel: Aiding the Occupation. New York: Pluto Press, p. 139.

23 European Friends of Israel. (2006). About EFI. August 20, http://www.efieu.org/index.php?option=com_k2\&view=item\&layout=item\&id=269\&Itemid=145\#.VE5qi_msVKA (accessed 20 September 2014). 
${ }^{24}$ Cronin, D. (2014). European Friends of Israel: Founded by Tories, Funded by Big Business (Part 2). May 20, http://www.spinwatch.org/index.php/issues/lobbying/item/5655-europe-friends-of-israel-part-2 (accessed 17 August 2014).

25 European Friends of Israel. (2006). About EFI. August 20, http://www.efieu.org/index.php?option=com_k2\&view=item\&layout=item\&id=269\&Itemid=145\#.VE5qi_msVKA

12 (accessed 20 September 2014).

26 Transparency Register. (2011). Profile of Registrant- European Friends of Israel. August 11, http://ec.europa.eu/transparencyregister/public/consultation/displaylobbyist.do?id=69595906422-47 (accessed 20 August 2014).

${ }^{27}$ Cronin, D. (2014). European Friends of Israel: Founded by Tories, Funded by Big Business (Part 1). May 20, http://www.spinwatch.org/index.php/issues/lobbying/item/5654-european-friends-of-israel-founded-bytories-funded-by-big-business (accessed 17 August 2014); Cronin, D. 2014a. European Friends of Israel: founded by Tories, funded by big business (Part 2). May 20, http://www.spinwatch.org/index.php/issues/lobbying/item/5655-europe-friends-of-israel-part-2 (accessed 17 August 2014).

${ }^{28}$ Israel National News. (2006). Parliamentarians Unite across Europe to Support Israel. September 15, http://www.israelnationalnews.com/News/Flash.aspx/112094\#.VE99xPmsVKA (accessed 21 September 2014).

${ }^{29}$ European Friends of Israel. (2007). Cocktail Dinner for the Inauguration of EFI New Offices. October 10, http://www.israelnationalnews.com/News/Flash.aspx/112094\#.VE99xPmsVKA (accessed 21 September 2014).

30 European Friends of Israel. (2008). Meetings with MK Reuven Rivlin. June 9, http://www.efieu.org/index.php?option=com_k2\&view=item\&id=234:meetings-with-mk-reuven-rivlin\#.VE-g-fmsVKA (accessed 21 September 2014).

${ }^{31}$ Israel Ministry of Foreign Affairs. (2013). President Peres on State Visit to the European Union. March 5, http://mfa.gov.il/MFA/PressRoom/2013/Pages/President-Peres-state-visit-European-Union-5-Mar-

2013.aspx (accessed 21 September 2014).

${ }^{32}$ European Friends of Israel. (2013). Meeting with Shimon Peres, the President of the State of Israel at the European Parliament. March $\quad 6, \quad$ http://www.efieu.org/index.php?option=com_k2\&view=item\&id=326:meeting-with-shimon-peres-the-president-of-thestate-of-israel-at-the-european-parliament\&Itemid=141\#.VFIIt_msVKA (accessed 21 September 2014).

${ }^{33}$ European Friends of Israel. (2013). EFI Political Board meets with President of EP Martin Schulz. March 6, http://www.efi-eu.org/index.php?option=com_k2\&view=item\&id=327:efi-political-board-meets-withpresident-of-ep-martin-schultz\#.VFIWwPmsVKA (accessed 21 September 2014).

34 Times of Israel. (2014). Palestinian Security Prisoners Declare Massive Hunger Strike. May 21, http://www.timesofisrael.com/palestinian-security-prisoners-declare-massive-hunger-strike/ (accessed 24 September 2014).

${ }^{35}$ European Union. (2013). Statement by the Spokesperson of High Representative Catherine Ashton on the Condition of Palestinian Hunger Strikes in Israel. A 88/13, February 16, http://www.consilium.europa.eu/uedocs/cms_Data/docs/pressdata/EN/foraff/135506.pdf $\quad$ (accessed 24 September 2014).

36 European Parliament. (2012). Israel's Policy of Administrative Detention. Directorate-General for External Policies of the Union Policy Department, http://www.europarl.europa.eu/RegData/etudes/briefing_note/join/2012/491444/EXPO-

AFET_SP(2012)491444_EN.pdf (accessed 24 September 2014).

37 European Friends of Israel. (2013). Briefing on Palestinian Security Prisoners at the European Parliament. June 25, http://www.efi-eu.org/index.php?option=com_k2\&view=item\&id=344:briefing-onpalestinian-security-prisoners-at-the-euopean-parliament\#.VFJOE_msVKA (accessed 24 September 2014). 38 European Friends of Israel. (2006). Conference 'Israeli kidnapped soldiers'. November 29, http://www.efi-eu.org/index.php?option=com_k2\&view=item\&id=220:conference-israeli-kidnappedsoldiers\&Itemid=141\#.VFNIY_msVKA (accessed 27 September 2014).

39 European Friends of Israel. (2007). Conference 'Economic Sanctions against Iran'. March 7, http://www.efi-eu.org/index.php?option=com_k2\&view=item\&id=219:conference-economic-sanctionsagainst-iran\&Itemid=141\#.VFNqTPmsVKA (accessed 29 September 2014).

${ }^{40}$ European Friends of Israel. (2012). MEP Alejo Vidal Quadras Hosts First 2012 EFI Conference on Iran. February 9, http://www.efi-eu.org/index.php?option=com_k2\&view=item\&id=223:mep-alejo-vidalquadras-hosts-first-2012-efi-conference-on-iran\&Itemid=141\#.VFdp-vmsVKA (accessed 29 September 2014). 
41 European Friends of Israel. (2008). EFI Policy Conference 2008. November 11, http://www.efieu.org/index.php?option=com_k2\&view=item\&id=238:efi-policy-conference-

2008\&Itemid=141\#.VFNrJ_msVKA (accessed 29 September 2014).

42 Jerusalem Post. (2008). EU MPs Urged to Rethink Refugee Issue. November 10, http://www.jpost.com/Israel/EU-MPs-urged-to-rethink-refugee-issue (accessed 29 September 2014).

${ }^{43}$ European Jewish Congress. (2008). Noam Shalit: We are More and More Worried about Gilad's Fate. November 7, http://www.eurojewcong.org/20/3001-noam-shalit:-\%E2\%80\%98we-are-more-and-moreworried-about-gilads-fate.html (accessed 29 September 2014).

44 CBN News. (2007). Call Me Infidel: An Ex-Muslim Speaks Out. CBN News, March 27, http://www.cbn.com/tv/1422246203001 (accessed 30 September 2014).

45 European Friends of Israel. (2009). Hamas: Obstacle to Peace. April 24, http://www.cbn.com/tv/1422246203001 (accessed 30 September 2014).

${ }^{46}$ Ibid.

${ }^{47}$ Cronin, D. (2011). The Rise of the Israel Lobby in Europe. In The Battle for Public Opinion in Europe: Changing Perceptions of the Palestine-Israel Conflict, eds. D. Abdullah and I. Hewitt, 43-73. London: MEMO Publishers, p. 41-2.

48 Cronin, D. (2011). Israel's European Friends Get Active. Inter Press Service, January 25, http://www.ipsnews.net/2011/01/israelrsquos-european-friends-get-active/ (accessed 1 November 2014).

49 Netanyahu, B. (2011). Address by PM Netanyahu to the European Friends of Israel Conference in Jerusalem", Israel Ministry of Foreign Affairs, February 7, http://mfa.gov.il/MFA/PressRoom/2011/Pages/PM_Netanyahu_European_Friends_Israel_7-Feb-2011.aspx (accessed 1 November 2014).

50 European Friends of Israel. (2011). 2nd Policy Conference, Jerusalem/Israel. http://www.blog.paixjuste.lu/wp-content/uploads/2011/01/EFI-2nd-Policy-Conference-T-2011.pdf (accessed 2 November 2014).

${ }^{51}$ European Commission. (2011). Implementation of the European Neighbourhood Policy in 2010 Country Report: $\quad$ Israel. $\quad$ Brussels, $\quad$ SEC(2011) 642, May 25 , http://eeas.europa.eu/enp/pdf/pdf/progress2011/sec_11_642_en.pdf (accessed 3 November 2014).

52 The Canadian Jewish News. (2012). Feminist MK Talks Hasbarah with Halifax Jews. April 7, 2012, http://www.cjnews.com/canada/feminist-mk-talks-hasbarah-halifax-jews (accessed 3 November 2014).

${ }^{53}$ European Friends of Israel. (2014). Myths and Reality - EFI Conference. January 23, http://www.efieu.org/index.php?option=com_k2\&view=item\&id=370:myths-and-reality-efi-conference\#.VFjnSPmsVKA (accessed 3 November 2014).

${ }^{54}$ Cronin, D. (2014). European Friends of Israel: Founded by Tories, Funded by Big Business (Part 2). May 20, http://www.spinwatch.org/index.php/issues/lobbying/item/5655-europe-friends-of-israel-part-2 (accessed 17 August 2014).

55 The New York Times. (2013). European Union Adds Military Wing of Hezbollah to List of Terrorist Organizations. July 22, http://www.nytimes.com/2013/07/23/world/middleeast/european-union-addshezbollah-wing-to-terror-list.html?pagewanted=all\&_r=0 (accessed 3 November 2014).

56 European Friends of Israel. (2008). Written Declaration. June 13, http://www.efieu.org/index.php?option=com_k2\&view=item\&id=228: written-declaration\&Itemid=141\#.VFooPvmsVKA (accessed 4 November 2014).

57 Financial Times. (2013). EU under Pressure over Funding in Israel Settlements. September 8, http://www.ft.com/intl/cms/s/0/b28e4dd0-1880-11e3-83b9-00144feab7de.html\#axzz3ID0fTmMh (accessed 5 November 2014).

${ }^{58}$ European Commission. (2013). Guidelines on the Eligibility of Israeli Entities and their Activities in the territories Occupied by Israel since June 1967 for Grants, Prizes and Financial Instruments Funded by the EU from 2014 onwards. Official Journal of the European Union, 2013/C 205/5, http://eeas.europa.eu/delegations/israel/documents/related-

links/20130719_guidelines_on_eligibility_of_israeli_entities_en.pdf (accessed 2 October 2014).

${ }^{59}$ European Friends of Israel. (2013). EFI Released an Open Letter about the EU Guidelines. October 22, http://www.efi-eu.org/index.php?option=com_k2\&view=item\&id=355:efi-released-an-open-letter-aboutthe-eu-guidelines\&Itemid=141\#.VFpaKPmsVKA (accessed 5 November 2014).

${ }^{60}$ Ynetnews. (2013). EU Lawmakers Urge Ashton to Rethink Settlement Boycott Guidelines. November 13, http://www.ynetnews.com/articles/0,7340,L-4453298,00.html (accessed 5 November 2014).

61 European Friends of Israel. (2007). EFI Mission to Portugal. January 25, http://www.efieu.org/index.php?option=com_k2\&view=item\&id=211:efi-mission-to-portugal\&Itemid=141 (accessed 8 November 2014). 
62 European Friends of Israel. (2007). EFI Mission to Spain. February 20, http://www.efieu.org/index.php?option=com_k2\&view=item\&id=210:efi-mission-to-spain\&Itemid=141\#.VHbWxJVxl1s (accessed 8 November 2014); European Friends of Israel. 2007e. EFI mission to Malta. May 5, http://www.efi-eu.org/index.php?option=com_k2\&view=item\&id=212:efi-mission-tomalta\&Itemid=141\#.VHbXXpVxl1s (accessed 8 November 2014).

| $14 \quad{ }^{63}$ European Friends of Israel. (2012). EFI Political Board Meeting with Shimon Peres and Visit to Southern Israel. December 2, http://www.efi-eu.org/index.php?option=com_k2\&view=item\&id=316:efi-politicalboard-meeting-with-shimon-peres-and-visit-to-southern-israel\&Itemid=141\#.VHbX-JVxl1s $\quad$ (accessed 8 November 2014).

${ }^{64}$ European Friends of Israel. (2009). European Holocaust Remembrance Day. January 28, http://www.efieu.org/index.php?option=com_k2\&view=item\&id=215:european-holocaust-remembranceday\&Itemid=141\#.VHbaDJVxl1s (accessed on 8 November 2009).

${ }^{65}$ European Friends of Israel. (2009). Mission to Israel 'Understanding the Ongoing Situation'. January 6, http://www.efi-eu.org/index.php?option=com_k2\&view=item\&id=214:mission-to-israel-understanding-theongoing-situation\&Itemid=141\#.VGH0lfmsVKA (accessed 8 November 2014).

${ }^{66}$ European Friends of Israel. (2013). Policy Advisers Tour to Israel. June 18, http://www.efieu.org/index.php?option=com_k2\&view=item\&id=343:policy-advicers-tour-to-

israel\&Itemid=141\#.VGH1GfmsVKA (accessed 8 November 2014). 